\title{
POLYMORPHISM OF BUCKWHEAT SEED STORAGE PROTEINS IN CULTIVAR GROUPS, DIFFERING BY THEIR MORPHOTYPE
}

\author{
Ye. V. Zaika ${ }^{1}$, N. A. Kozub ${ }^{2,3}$, I. A. Sozinov ${ }^{2}$, G. Ya. Bidnyk ${ }^{2,3}$, P. P. Karazhbey ${ }^{1}$ \\ ${ }^{1}$ NSC "Institute of Agriculture" NAAS, 2b, Mashynobudivnykiv Str., Chabany village, Kyiv-Sviatoshyn District, 08163 \\ ${ }^{2}$ Institute of Plant Protection, NAAS, 33, Vasylkivska Str., Kyiv 03022 \\ ${ }^{3}$ Institute of Food Biotechnology and Genomics, NAS of Ukraine
}

2a, Osypovskoho Str., Kyiv 04123

E-mail: za-ika@ukr.net

Received December 26, 2018 / Received February 26, 2019 / Accepted March 22, 2019

\begin{abstract}
Aim. To study polymorphism of buckwheat seed proteins in cultivar groups of different morphotypes by the color of corolla. Methods. Electrophoresis by Laemmli method in $17.5 \%$ separating PAAG gel. Results. Electrophoresis spectrum variants with the incidence from 1 to $76 \%$, common for buckwheat cultivar groups, which are different in their morphotype, were revealed. The obtained results demonstrate a particular level of heterogeneity by the revealed variants in each investigated group of buckwheat genotypes. Variants $2 h$ and $4 f$, occurring with the incidence of $10 \%$ and $8 \%$ respectively, and specific for green-flowered group of buckwheat cultivars, were also revealed. Conclusions. Different incidence of electrophoresis spectrum components in buckwheat morphotypes, different in flower coloring, demonstrates probable different selective value of genes, which control the synthesis of these components or their relation to the genes, closely bound to them. Taking this fact into consideration, buckwheat seed proteins may be molecular and genetic markers for identification of some buckwheat morphotypes, which may be used in breeding programs.
\end{abstract}

Keywords: edible buckwheat, storage proteins, globulins, albumins, polymorphism.

DOI:

\section{INTRODUCTION}

Buckwheat (Fagopyrum esculentum Moench.) is a valuable cereal crop, grown in China, Japan, Poland, Germany, in the Balkans, Hungary, the Czech Republic, Slovakia, Italy, France, the USA, Canada, India, Australia, the Russian Federation and other countries. The global area of buckwheat fields is about 2-2.5 million ha, most of which are located in mountainous regions. According to the data of the State Statistics Service, in recent years the Ukrainian fields of edible buckwheat have fluctuated in the range from 132.8 thousand ha to 311.2 thousand ha.

Food products, made of buckwheat, have high nutritional value and unique combination of positive therapeutic-dietary properties $[1,2]$. The experts of the International Plant Genetic Resources Institute (IPGRI) and Consultative Group on International Agricultural Research (CGIAR) consider edible buckwheat to be a crop of the future [3]. It is ex-

(C) Ye.V. ZAIKA, N. O. KOZUB, I. O. SOZINOV,

G. Ya. BIDNYK, P. P. KARAZHBEY, 2019 plained by high protein content (from 10 to $18 \%$ ) which has high availability, nutritional value and balance of aminoacid composition [1].

Buckwheat seed storage proteins constitute the larger part of total protein in the seed and play an important role as a source of nitrogen in the nutrition of seedlings during the initial phases of development $[4,5]$. Storage proteins are composed of two main classes: saltsoluble globulins and water-soluble albumins [4]. Albumins have a sedimentation coefficient in the range of 1.7-2S whereas globulins have a sedimentation coefficient in the range between $7 \mathrm{~S}$ and $8 \mathrm{~S}$ which is notable for vicilin-like proteins and a sedimentation coefficient in the range from 11 to $13 \mathrm{~S}$, notable for legumin-like proteins [5]. It was established that the most significant fraction of buckwheat proteins is $13 \mathrm{~S}$ globulin which constitutes about $33 \%$ from storage proteins of the seed and belongs to legumin-like proteins [6]. It consists of two non-identical subunits: a larger one of 32 $43 \mathrm{kDa}$ and the other one $-23-25 \mathrm{kDa}$, connected with a disulphide bond [5]. Minor classes of $8 \mathrm{~S}$ globulins 
and $2 \mathrm{~S}$ albumins, which constitute about $6.5 \%$ from total protein of the seed have recently been identified $[6,7]$. It was found that the fraction of $8 \mathrm{~S}$ globulins is three-link polymers which consists of subunits with the mass of $57-58 \mathrm{kDa}$ and belongs to vicilin-like storage proteins [6]. $2 \mathrm{~S}$ fraction of albumins, constituting $25 \%$ from the total number of seed proteins, is presented with a single-chain polypeptide with the molecular mass of $8-16 \mathrm{kDa}$ and is rich in essential aminoacids (9.2\% methionine and $5.6 \%$ lysine) [6]. The investigation of polymorphism of buckwheat storage proteins is relevant for the study of evolution of this crop, for the determination of processes, occurring in buckwheat populations under the impact of ecological factors and the pressure of the breeding process $[8,9]$. It was proven that there is a possibility of using storage proteins as genetic markers for other agricultural crops in the links of the breeding process and seed production [10], for passportization of cultivars [11]. Taking into consideration the fact that buckwheat is a valuable groat crop, this genetic evaluation of variability, including polymorphism of seed storage proteins, is relevant for the creation of lines with required characteristics and elaboration of efficient breeding programs $[12,13]$.

The use of molecular and genetic markers in breeding edible buckwheat is complicated with the fact that this crop is poorly yielding to inbreeding, and the most valuable cultivars are mostly highly heterogeneous synthetic populations [14]. It is related to the phenomenon of self-incompatibility which excludes the possibility of self-pollination and, if a sufficient number of natural pollinating insects is present, creates conditions for maintaining a high level of heterozygosity of the population. However, some investigations of genetic diversity of edible buckwheat were conducted using specific electrophoresis methods of storage proteins, which were used to reveal moderate internal and interspecific polymorphism [15-17]. There are active current efforts of introgression of self-compatibility genes from Fagopyrum homotropicum Ohnishi species into the genome of edible buckwheat which helped create homozygous genetic material for studies [14]. The obtained results demonstrate probable monogenic control of inheriting buckwheat storage proteins [6]. However, despite genetic proximity of $F$. esculentum and F. homotropicum, the progeny, obtained from their hybridization may be a robust genetic model for studies.

Different scientists believe that despite poor diversity of cultivated buckwheat there are differences between different morphotypes at the levels of both phenotype and genotype. For instance, some samples with red or dark pink flowers originate from high mountainous districts of China and Nepal and some scientists relate their occurrence to buckwheat spreading to colder regions of the globe [18]. Green-flower variety of buckwheat was artificially bred from the mutant population in Ukraine, in the Institute of Grain Crops at the Podilsky State Agrarian Technical University (KamianetsPodilsky) [19]. It was used as a basis to create a group of cultivars, characterized by seeds fall resistance. White-flower genotypes are wide-spread: white color of corolla is dominant in terms of green- and red-flower genotypes, thus it is considered a wild type [18]. The color of corolla may have been the phenotype marker, used by ancient agrarians to unconsciously select local buckwheat cultivars both prior to synthetic breeding and during the period of wide application of mutagenesis and hybridization in the $20^{\text {th }}$ century which may be traced in differences at the level of storage proteins.

The work was aimed at investigating polymorphism of storage proteins of edible buckwheat of Ukrainian, Belorussian and Russian breeding and the search for differences by the incidence of electrophoretic variants of cultivar groups, differing by corolla color.

\section{MATERIALS AND METHODS}

The material for investigations was obtained from Ustymivska experimental station of the Institute of Plant Production named after V.Ya. Yuriev, of NAAS green-flower cultivars of buckwheat: Zelenokvitko-

Table 1. Characteristics of investigated samples by their origin and flower morphotype

\begin{tabular}{l|c|c|c}
\hline \multicolumn{1}{c|}{ Cultivar } & $\begin{array}{c}\text { Corolla } \\
\text { color }\end{array}$ & $\begin{array}{c}\text { Coun- } \\
\text { try }\end{array}$ & Group \\
\hline Zelenokvitkova-90 & Green & UKR & \\
Zelenokvitkova-10 & Green & UKR & \\
Zelenokvitkova-16 & Green & UKR & I \\
Zelenokvitkova-12 & Green & UKR & \\
Zelenokvitkova-22 & Green & UKR & \\
Rozhevokvitkova-1 & Red & BLR & \\
Chervonokvitkova & UKR & \\
Rubinova & Red & UKR & II \\
Rozhevokvitkova produktyvna & RKR & \\
Bashkyrskaia krasnotsvetkovaia & Red & RUS & \\
Lakneia & White & BLR & \\
Vlada & White & BLR & \\
Belorusskaya homostilnaia & White & BLR & III \\
Olha & White & UKR & III \\
Ukrainka & White & UKR & \\
\hline
\end{tabular}




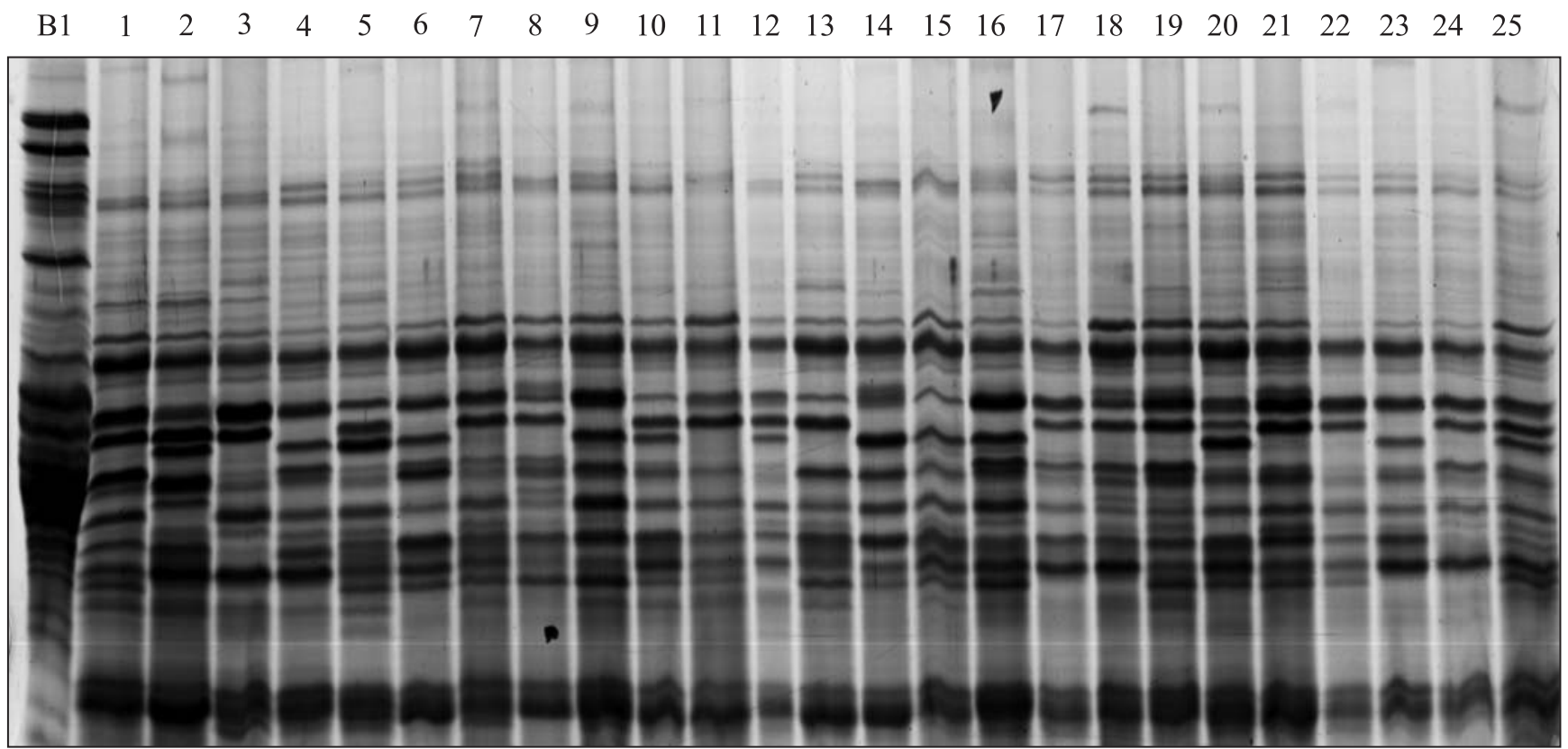

Fig. 1. Electrophoregrams of storage proteins: B1 - soft wheat Bezosta-1, 1-5 - buckwheat cultivar Rozhevokvitkova-1, 6-15 - buckwheat cultivar Rozhevokvitkova produktyvna, 16-25 - buckwheat cultivar Rubinova

va-10, Zelenokvitkova-90, Zelenokvitkova-16, Zelenokvitkova-22, Zelenokvitkova-12; red-flower cultivars: Bashkyrskaia krasnotsvetkovaia, Chervonokvitkova, Rozhevokvitkova produktyvna, Rozhevokvitkova-1, Rubinova and white-flower cultivars: Ukrainka, Lakneia, Vlada, Belorusskaya homostilnaia and Olha (Table 1). The cultivars were divided into groups by the color of corolla: red-flower - group I, green-flower group II and white-flower - group III.

The electrophoretic spectrum of storage proteins of buckwheat was studied in 10-30 separate grains of each cultivar. For this reason, a ground seed was covered with $400 \mu 1$ of the extraction buffer and kept overnight with subsequent centrifugation, the precipitate was isolated and heated for $10 \mathrm{~min}$ on boiling water bath. The SDS electrophoresis by Laemmli method in $17.5 \%$ separating gel was conducted [20].

A biochemical approach was used to register some spectrum components in all investigated cultivars. To describe polymorphism, the electrophoregrams of storage proteins were nominally divided into four zones - A, B, C, D (Fig. 2). Fisher's exact test and chisquare $\left(\chi^{2}\right)$ were used for statistical evaluation of incidence allocation.

\section{RESULTS AND DISCUSSION}

Polymorphism in the investigated cultivars was determined in A, B, C, D areas of the obtained electrophoretic spectrum of protein separation. A total of about 60 components of different intensity were identified (Table 2, Fig. 1, Fig. 2, Fig. 3).

Two variants -1 and $1 a-$ were identified in the area of electrophoretic spectrum A among the whole selection of cultivars. The incidence of variant 1 was $58 \%$ for white-flower samples, whereas for green-flower and red-flower samples it was 70 and $76 \%$ respectively. Somewhat higher incidence of variant $l a$ in the same spectrum zone was noted for white-flower cultivars, but these differences were not statistically reliable.

Eleven variants were identified in zone B of the electrophoretic spectrum by all the cultivars. By the incidence of spectrum variants $2 a, 2 j, 2 h$, statistically reliable differences between red-flower and white-flower groups of genotypes were also determined at $\mathrm{P}<0.05$.

Statistically reliable differences were also observed between groups of green-flower and white-flower genotypes $(\mathrm{P}<0.05)$. Variant 2 was observed with the incidence of $35 \%$ in white-flower cultivars, with only $14 \%$ in green-flower cultivars, which was statistically reliable $(\mathrm{P}<0.05)$.

Components, specific for particular groups of buckwheat cultivars, were also revealed. Variant $2 h$ is inherent only for some green-flower genotypes and has the incidence of $10 \%$, which demonstrates statistically reliable difference from other groups of genotypes $(\mathrm{P}<0.05)$. Electrophoretic variant $2 j$ was also found in red-flower and white-flower genotypes with the in- 


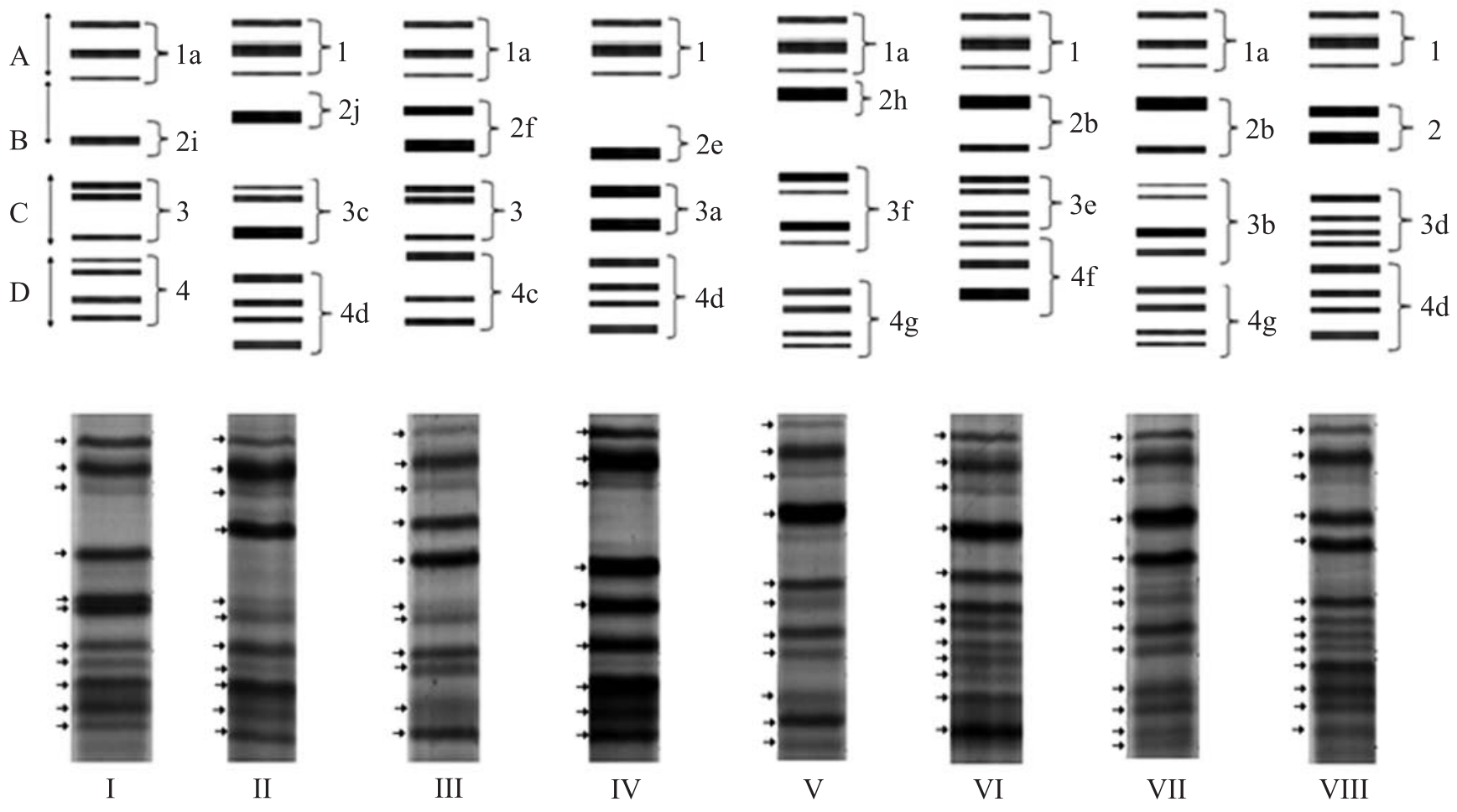

Fig. 2. Schemes of variants of buckwheat storage proteins (up) and their corresponding electrophoretic spectra (down): I - Bashkyrskaia krasnotsvetkovaia; II - Belorusskaya homostilnaia; III - Vlada; IV - Zelenokvitkova-10; VI Zelenokvitkova-16; VII - Zelenokvitkova-162; VIII - Zelenokvitkova-90
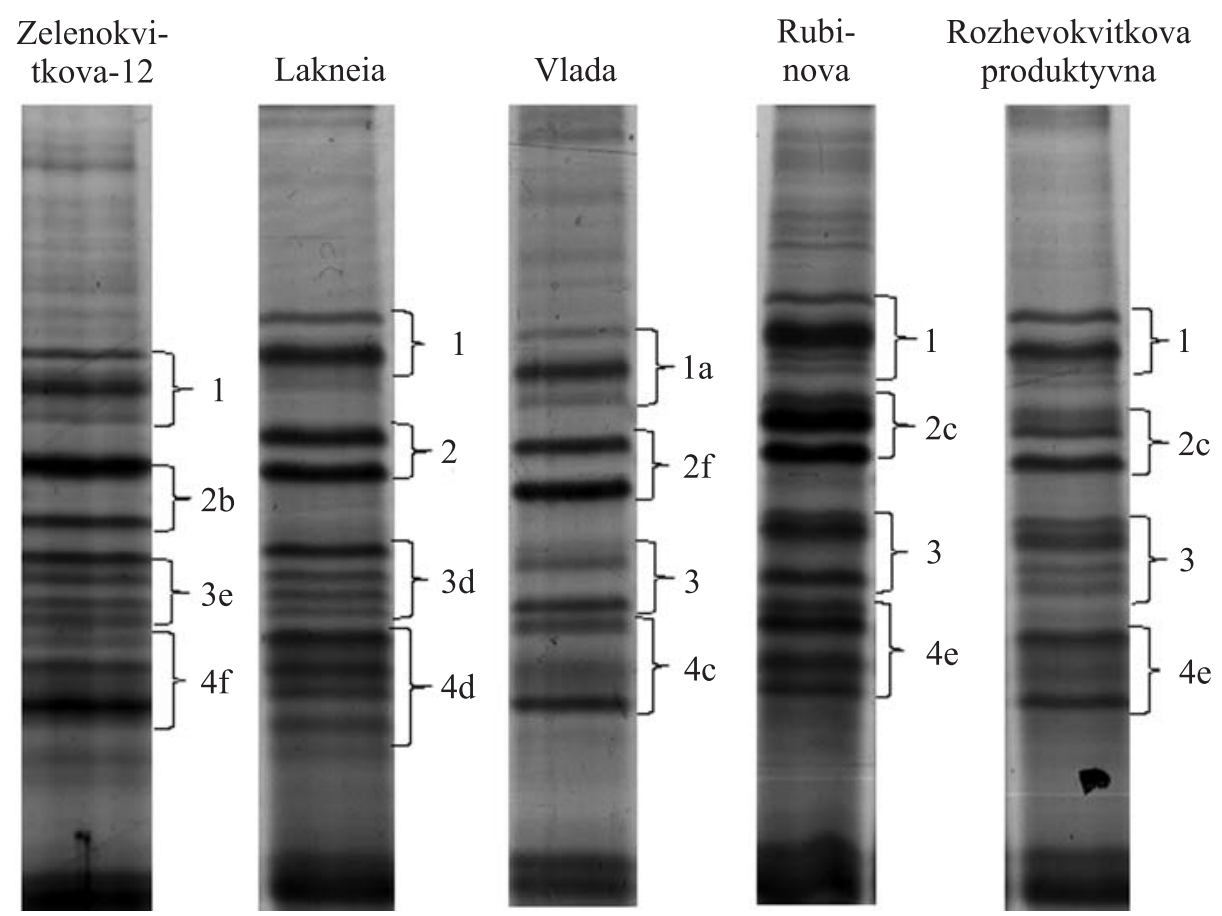

Fig. 3. Variants of electrophoretic spectra of buckwheat seed storage proteins (SDS electrophoresis in $17.5 \%$ PAAG gel)

cidence of $14 \%$, which has statistically reliable $(\mathrm{P}<$ $<0.05)$ difference from the green-flower group of buckwheat cultivars, where it was not identified. The variants of electrophoretic spectrum $2 f, 2 g$, observed with the similar incidence in all three groups of cultivars, were determined. 
ZAIKA et al.

Table 2. Distribution of incidence of alleles for different groups of buckwheat cultivars

\begin{tabular}{|c|c|c|c|c|c|c|}
\hline \multirow[b]{2}{*}{$\begin{array}{l}\text { Spectrum } \\
\text { variants }\end{array}$} & \multicolumn{2}{|c|}{ Group I } & \multicolumn{2}{|c|}{ Group II } & \multicolumn{2}{|c|}{ Group III } \\
\hline & $\begin{array}{l}\text { Number } \\
\text { of seeds }\end{array}$ & $\begin{array}{c}\text { Incidence } \\
\text { of variants } \\
\text { in cultivars } \\
\text { with red } \\
\text { corolla, \% }\end{array}$ & $\begin{array}{l}\text { Number } \\
\text { of seeds }\end{array}$ & $\begin{array}{l}\text { Incidence } \\
\text { of variants } \\
\text { in cultivars } \\
\text { with green } \\
\text { corolla, \% }\end{array}$ & $\begin{array}{l}\text { Number } \\
\text { of seeds }\end{array}$ & $\begin{array}{l}\text { Incidence } \\
\text { of variants } \\
\text { in cultivars } \\
\text { with white } \\
\text { corolla, \% }\end{array}$ \\
\hline \multicolumn{7}{|c|}{$A$} \\
\hline 1 & 38 & 76 & 35 & 70 & 29 & 58 \\
\hline $1 a$ & 12 & 24 & 15 & 30 & 21 & 42 \\
\hline Total & 50 & 100 & 50 & 100 & 50 & 100 \\
\hline \multicolumn{7}{|c|}{$B$} \\
\hline 2 & 14 & 28 & $7 *$ & 14 & $17 *$ & 35 \\
\hline $2 a$ & $3 *$ & 6 & 8 & 16 & $10^{*}$ & 20 \\
\hline $2 b$ & 5 & 10 & 12 & 24 & 5 & 10 \\
\hline $2 c$ & 7 & 14 & 2 & 4 & 1 & 2 \\
\hline $2 d$ & 3 & 6 & 6 & 12 & 1 & 2 \\
\hline $2 e$ & 0 & 0 & 0 & 0 & 1 & 2 \\
\hline $2 f$ & 3 & 6 & 3 & 6 & 2 & 4 \\
\hline $2 g$ & 5 & 10 & 5 & 10 & 5 & 10 \\
\hline $2 h$ & $0^{*}$ & 0 & $5 * / * *$ & 10 & $0 * *$ & 0 \\
\hline $2 i$ & 3 & 6 & 1 & 2 & 0 & 0 \\
\hline $2 j$ & $7 *$ & 14 & $0 * / * *$ & 0 & $7 * *$ & 14 \\
\hline Total & 50 & 100 & 49 & 100 & 49 & 100 \\
\hline \multicolumn{7}{|c|}{$C$} \\
\hline 3 & 25 & 51 & 18 & 37 & 19 & 39 \\
\hline $3 a$ & 4 & 8 & 3 & 6 & 4 & 8 \\
\hline $3 b$ & 5 & 10 & 11 & 22 & 9 & 18 \\
\hline $3 c$ & 10 & 20 & 5 & 10 & 6 & 12 \\
\hline $3 d$ & 1 & 2 & 0 & 0 & 1 & 2 \\
\hline $3 e$ & $4^{*}$ & 8 & $11^{*}$ & 22 & 10 & 20 \\
\hline $3 f$ & 0 & 0 & 1 & 2 & 0 & 0 \\
\hline Total & 49 & 100 & 49 & 100 & 49 & 100 \\
\hline \multicolumn{7}{|c|}{$D$} \\
\hline 4 & $18^{*}$ & 36 & $15^{*}$ & 31 & 4 & 8 \\
\hline $4 a$ & 11 & 22 & 11 & 22 & 19 & 38 \\
\hline $4 b$ & 3 & 6 & 2 & 4 & 1 & 2 \\
\hline $4 c$ & 5 & 10 & $1 *$ & 2 & $9^{*}$ & 18 \\
\hline $4 d$ & 10 & 20 & 10 & 20 & 10 & 20 \\
\hline $4 e$ & 2 & 4 & 1 & 2 & 1 & 2 \\
\hline $4 f$ & $1^{*}$ & 2 & $8 * / * *$ & 16 & $1 * *$ & 2 \\
\hline $4 g$ & 0 & 0 & 1 & 2 & 5 & 10 \\
\hline Total & 50 & 100 & 49 & 100 & 50 & 100 \\
\hline
\end{tabular}

Note/. * Reliable difference at $\mathrm{P} \leq 0.05$ in variant 2 between cultivar groups II and III $\left(\mathrm{p}=0.019, \chi^{2}=5.52\right)$; reliable difference at $\mathrm{P} \leq 0.05$ in variant $2 \boldsymbol{a}$ between cultivar groups I and III $\left(\mathrm{p}=0.033, \chi^{2}=4.5\right)$; ** - reliable difference at $\mathrm{P} \leq 0.05$ in variant $2 j$ between cultivar groups I, II and II, III ( $\mathrm{p}=0.012)$; reliable difference at $\mathrm{P} \leq 0.05$ in variant $\boldsymbol{2} \boldsymbol{h}$ between cultivar groups I, II and II, III (p $=0.027) ; *-$ reliable difference at $\mathrm{P} \leq 0.05$ in variant $3 \boldsymbol{e}$ between cultivar groups I, II $\left(\mathrm{p}=0.049, \chi^{2}=3.86\right)$; reliable difference at $\mathrm{P} \leq 0.05$ in variant 4 between cultivar groups II and III ( $\left.\mathrm{p}=0.018, \chi^{2}=5.57\right)$; reliable difference at $\mathrm{P} \leq 0.05$ in variant 4 between cultivar groups I and III ( $\mathrm{p}=0.004$, $\left.\chi^{2}=8.13\right)$; reliable difference at $\mathrm{P} \leq 0.05$ in variant $4 c$ between II and III $\left(\mathrm{p}=0.016, \chi^{2}=7.11\right)$; $* *-$ reliable difference at $\mathrm{P} \leq 0.05$ in variant $4 f$ between cultivar groups I and II, and between II and III $\left(\mathrm{p}=0.016, \chi^{2}=8.13\right)$; table value $\chi^{2}=3.84$ at $\mathrm{f}=1, \mathrm{P}=0.05$ 
The incidence of variant $2 g$ was $10 \%$ for all the groups of genotypes. Variant $2 f$ was observed in cultivar groups I and II with the incidence of $6 \%$ and group III $-4 \%$. The lowest incidence in the zone of electrophoretic spectrum B among buckwheat genotypes was observed for variants $2 f, 2 i, 2 e-1-3 \%$. The highest incidence in zone $\mathrm{B}$ among green-flower genotypes was observed for variants 2 (28 and $35 \%$ ) in cultivar groups with red and white corolla respectively and $2 b$ $(24 \%)$ - in a cultivar group with green corolla.

Seven variants were identified for zone $\mathrm{C}$ of the electrophoretic spectrum of buckwheat. Variant 3 had the highest incidence $(37-51 \%)$ in all the cultivar groups of buckwheat in zone $\mathrm{C}$. The incidence of variant $3 a$ was also close in all the cultivar groups where it was $6-8 \%$. There were considerable differences $(\mathrm{P}<0.05)$ between the incidence of variant $3 e$ of electrophoretic spectrum for red-flower $(8 \%)$ and green-flower $(22 \%)$ cultivar groups, and it was $20 \%$ in white-flower cultivars.

Eight components were revealed in zone D of the electrophoretic spectrum, the highest incidence being registered for variant 4 (31 and $36 \%$ ) in red-flower and green-flower cultivars of buckwheat respectively. At the same time, this variant was identified only in $8 \%$ of genotypes in white-flower cultivars. The difference between the incidence of this variant in cultivar groups is reliable $(\mathrm{P}<0.05)$ for red-flower and white-flower genotypes, and also for green-flower and white-flower groups of genotypes. The incidence of variant $4 a$ was high (22-38\%) for all the groups of cultivars, but no statistically reliable difference was determined between them by this variant. Variant $4 c$ is observed in white-flower cultivars with the incidence of $18 \%$, whereas the incidence for green-flower and red-flower genotypes is 2 and $10 \%$ respectively. The difference in the incidence of variant $4 c$ between cultivar groups is statistically reliable for green-flower and white-flower genotypes ( $\mathrm{P}<0.05)$, being 2 and 18 $\%$ respectively. The highest incidence for variant $4 f$ was observed for green-flower group of cultivars (16 $\%$ ), whereas in other groups its incidence was only 2 $\%$, and this difference was statistically reliable $(\mathrm{P}<$ $0.05)$. Variant $4 d$ had the same incidence for all the cultivars $-20 \%$.

Variants $4 g, 4 b, 4 e$ did not have high incidence $2-10 \%$ in all the cultivar groups. Variant $4 g$ was not observed in red-flower cultivar group, but this difference from other groups of cultivars was not statistically reliable.
Thus, polymorphism by incidence of storage protein variants was observed in zones $\mathrm{B}, \mathrm{C}$, and $\mathrm{D}$ of the electrophoretic spectrum. Statistically reliable differences were observed in some variants between cultivar groups, different in their corolla coloring. No statistically reliable differences between different groups of cultivars were determined in the zone of electrophoretic spectrum A by the incidence of variants 1 and $1 a$. A reliable difference between cultivar groups was revealed by variants $2,2 a, 2 h, 2 j$ in spectrum zone B. A reliable difference was also found between cultivar groups in the incidence of variant $3 e-$ zone of spectrum $\mathrm{C}$; variants $4,4 c, 4 f$ - zone of spectrum D. A minor variant $3 f$ was specific for green-flower group of genotypes, and variant $2 e$ - for white-flower group, but differences were not statistically reliable. A statistically reliable advantage was revealed in the white-flower group of genotypes compared to the green-flower group of cultivars in the incidence of variants 2 and $4 c$. In addition, green-flower genotypes had higher statistically reliable incidence of variants $2 h(10 \%)$ and $4 f(16 \%)$, compared to white- and red-flower groups of cultivars and higher incidence of variant $3 e(22 \%)$, compared to red-flower cultivars $-8 \%$. The variants, specific for this group, were not revealed in the red-flower group of cultivars, but a considerably higher incidence of variants $4(34 \%)$ and $2 j(14 \%)$ was notable compared to the green-flower group of cultivars (31 and $0 \%$ respectively).

High interspecific polymorphism for buckwheat cultivars was also described by Rogl and Javornik, who used the method of SDS-PAGE electrophoresis [13]. In the studies of F. Zeller et al. (2004), electrophoresis of storage proteins in polyacrylamide gel in the presence of SDS by the method of Yan et al. (2003) was used to identify buckwheat cultivars from different countries [15]. The authors made a conclusion on the presence of many alleles of the locus, encoding $13 \mathrm{~S}$ globulin in buckwheat [15]. A similar method was used in the work of Luthar et al., and the obtained results were used by the researchers as a basis for the assumption that the genes of globulin subunits are closely connected and are inherited as one locus [5] which is in agreement with the regularity of inheriting in the form of blocks of components, which was previously revealed by O.O. Sozinov while studying gliadins and high molecular glutinins of soft wheat [10].

Electrophoresis spectrum variants with different incidence, common for buckwheat cultivar groups, which 
are different in their morphotype, were revealed. The obtained results demonstrate a particular level of heterogeneity by the revealed variants in each investigated group of buckwheat genotypes. Variants $2 h$ and variant $4 f$, occurring with the incidence of 10 and $8 \%$ respectively, and specific for green-flowered group of buckwheat cultivars, were also revealed. Different incidence of electrophoresis spectrum components in buckwheat morphotypes, different in flower coloring, demonstrates probable different selective value of genes, which control the synthesis of these components or their relation to the genes, closely bound to them. It provides for targeted selection of genotypes depending on their morphotype. For instance, due to recessive inheriting and incomplete penetrance of the feature of green corolla coloring, protein markers may be used to breed genotypes by this feature. Therefore, further studies of storage proteins are promising for the involvement in the breeding process, and some variants of storage proteins may be used as markers to identify some morphotypes of buckwheat.

This article does not relate to any studies using humans and animals as investigation subjects.

Conflict of interests. The authors deny any conflict of interests.

Financing. This study did not receive any specific grant from the financing institutions in state, commercial or non-commercial sectors.

\section{Поліморфізм запасних білків насіння гречки у різних за морфотипом груп сортів \\ Є. В. Заїка ${ }^{1}$, Н. О. Козуб ${ }^{2,3}$, І. О. Созінов ${ }^{2}$, Г. Я. Бідник ${ }^{2,3}$, П. П. Каражбей ${ }^{1}$ \\ ${ }^{1}$ ННЦ «Інститут землеробства НААН», Києво- Святошинський р-н, смт Чабани, вул. Машинобудівників, 2б, 08163 \\ ${ }^{2}$ Інститут захисту рослин НААН, м. Київ, вул. Васильківська, 33, 03022 \\ ${ }^{3}$ Інститут харчової біотехнології і геноміки НАН \\ України, м. Київ, вул. Осиповського, 2а, 04123

$$
\text { e-mail: za-ika@ukr.net }
$$

Мета. Вивчення поліморфізму білків насінини гречки у групах сортів різних морфотипів за забарвленням віночка квітки. Методи. Метод електрофорезу за методикою Laemmli в 17,5\%-му розділяючому PAAG гелі. Результати. Виявлено спільні для усіх різних за морфотипом груп сортів гречки варіанти електрофоретичного спектра, що зустрічаються з частотами від 1 до 76 \%. Отримані результати вказують на наявність певного рівня гетерогенності за виявленими варіантами у кожної $з$ досліджуваних груп генотипів гречки. Також виявлено специфічні для зеленоквіткової групи сортів гречки варіанти $2 h$ та варіант $4 f$, що зустрічалися 3 частотою 10 і 8 \% відповідно. Висновки. Різна частота зустрічальності компонентів електрофоретичного спектра у відмінних за забарвленням квітки морфотипів гречки вказує на ймовірну різну селекційну цінність генів, що контролюють синтез цих компонентів, або їх зв>язок $з$ генами, тісно зчепленими 3 ними. Зважаючи на це, білки насіння гречки можуть бути молекулярногенетичними маркерами для ідентифікації деяких морфотипів гречки та використані у селекційних програмах.

Ключові слова: гречка їстівна, запасні білки, глобуліни, альбуміни, поліморфізм.

\section{Полиморфизм запасных белков семян гречихи у разных по морфотипу групп сортов}

Е. В. Заика ${ }^{1}$, Н. А. Козуб ${ }^{2,3}$, И. А. Созинов ${ }^{2}$, А. Я. Бидник ${ }^{2,3}$, П. Ф. Каражбей ${ }^{1}$

${ }^{1}$ ННЦ «Институт земледелия НААН», Киево-Святошинский р-н, пгт Чабаны, ул. Машиностроителей, 2б, 08163

${ }^{2}$ Институт защиты растений НААН., Киев, ул. Васильковская, 33, 03022

${ }^{3}$ Институт пищевой биотехнологии и геномики НАН Украины, Киев, ул. Осиповского, 2a, 04123

$$
\text { e-mail: za-ika@ukr.net }
$$

Цель. Изучение полиморфизма белков семена гречихи в группах сортов различных морфотипов по окраске венчика цветка. Методы. Метод электрофореза по методике Laemmli в 17,5\%-ном разделяющем PAAG геле. Результаты. В различных участках электрофоретического спектра сортов гречихи посевной идентифицировано полиморфизм. Выявлены общие для всех отличительных за морфотипом групп сортов гречихи варианты электрофоретического спектра, которые встречаются с различными частотами от 1 до 76 \%. Полученные результаты указывают на наличие определенного уровня гетерогенности за найденными вариантами в каждой из исследуемых групп генотипов гречихи. Также выявлены специфические для зеленоцветковой группы сортов гречихи варианты $2 h$ и вариант $4 f$, что встречались с частотой 10 и $8 \%$ соответственно. Выводы. Разная частота встречаемости компонентов электрофоретического спектра в различных по окраске цветка морфотипов гречихи указывает на вероятную различную селекционную ценность генов, контролирующих синтез этих компонентов, или их связь с генами, тесно сцепленных с ними. Ввиду специфичности определенных вариантов электрофоретического спектра запасные белки семян гречихи могут быть молекулярно-генетическими маркерами для идентификации некоторых морфотипов гречихи и использованы в селекционных программах.

Ключевые слова: гречка съедобная, запасные белки, глобулины, альбумины, полиморфизм. 


\section{POLYMORPHISM OF BUCKWHEAT SEED STORAGE PROTEINS IN CULTIVAR GROUPS}

\section{REFERENCES}

1. KreftI, Germ M. Organically grown buckwheat as a healthy food and a source of natural antioxidants. Agronomski Glasnik. 2008;4:397-406, https://hrcak.srce.hr/30478.

2. Ahmed A, Khalid N, Ahmad A, Abbasi N, LatifM, Randhawa $M$. Phytochemicals and biofunctional properties of buckwheat: A review. J. Agric. Sci. 2014;152(3):349-69. doi:10.1017/S0021859613000166.

3. Chrungoo N., Dohtdong L., Chettry U. Genome Plasticity in Buckwheat. Pool Diversity and Crop Improvement. Sustainable Development and Biodiversity. 2016;(7). doi: 10.1007/978-3-319-27096-8_7.

4. Radovic $S$, Maksimovic $V$. Lysine rich $18 \mathrm{kDa}$ storage polypeptide front buckwheat seed. Fagopyrum. 2002; 19:59-61.

5. Chrungoo N., Dohtdong L., Chettry U. Diversity in Seed Storage Proteins and Their Genes in Buckwheat. Mol. Breed. Nutrit. Aspects of Buckwheat. 2016;(31):387-96. doi: 10.1016/B978-0-12-803692-1.00031-6.

6. Radovic S, Maksimovic V, Varikonji-Gasic E. Characterization of buckwheat seed storage proteins. J. Agric. Food Chem. 1996;44(4):972-4. doi: 10.1021/jf950655x.

7. Radovic R, Maksimovic R, Brkljacic M, Varkonji Gasic I, Savic P. 2S Albumin from Buckwheat (Fagopyrum esculentum Moench) Seeds. J. Agric. Food Chem. 1999;47:(4)1467-70. doi: 10.1021/jf980778s.

8. Samardžic' J, Milisavljevic' M, Brkljacic' J, Konstantinovic' $M$, Maksimovic' $V$. Characterization and evolutionary relationship of methionine-rich leguminlike protein from buckwheat, Plant Physiol. Biochem. 2004;42(2):157-63. doi: 10.1016/j.plaphy.2003.11.001.

9. Lazareva T, Fesenko I. Electrophoresis Spectra of Total Seed Proteins of Artificial Amphidiploid Fagopyrum giganteum Krotov and its Parental Species F. tataricum Gaertn and $F$. symosum Meisn. Proceedings of the $9^{\text {th }}$ International Symposium on Buckwheat. Prague; 2004:299-301.

10. Sozinov A.A. Polymorphism of proteins and its significance in genetics and breeding. M.:Nauka.1985:152 (in Russian).

11. Konarev AV, Konarev VG, Gubareva NK, Peneva TI.
Seed proteins as markers in resolving the problems of genetic plant resources, selection and seed production. Cytol.Genet. 2000;34(2):91-104. PMID: 10857208 (in Russian).

12. Radovic S, Miljus-Djukic J, Samardiz J, Banovic B, Nikolic D, Milisavjevic M, Timotijevic G. Buckwheat as a Model Plant in Molecular Biology. Europ. J. Plant Sci. Biotech. 2012;6(2):11-6.

13. RoglS, JavornikB. Seed protein variation for identification of common buckwheat (Fagopyrum esculentum Moench) cultivars. Euphytica. 1996;87(2):111-17. doi: 10.1007/ BF00021883.

14. Mukasa Y, Suzuki T, Honda Y. Amethodology for heterosis breeding of common buckwheat involving the use of the self-compatibility gene derived from Fagopyrum homotropicum. Euphytica. 2010;172(2):207-14. doi: 10.1007/s10681-009-0047-9.

15.Zeller FJ, Weishaeupl H, Hsam Sai LK. Identification and Genetics of Buckwheat (Fagopyrum) Seed Storage Proteins. Proceedings of the $9^{\text {th }}$ International Symposium on Buckwheat. Prague. 2004:195-201.

16. Jianhui Li, Qingfu Chen Variation in Seed Protein Subunits among Species of the Genus Fagopyrum Mill. Proceedings of the $10^{\text {th }}$ International Symposium on Buckwheat. Yangling, Shaanxi, China, Northwest University. 2007:372-82.

17. YangYu-Xia, Wu Wei, ZhengYou-Liang, Cai Qian-Rong. Genetic Diversity of Storage Proteins in Cultivated Buckwheat. Pakistan J. Biol Sci. 2008;11(3):1662-8. doi: 10.3923/pjbs.2008.1662.1668.

18. Trygub OV, Liashenko VV. Sources of economic and breeding-valuable traits for buckwheat breeding (Fagopyrum esculentum Moench.). News of Poltava State Agrarian Academy. 2017(1-2):48-55. (in Ukrainian).

19. Suzuki T, Mukasa Y, Morishita T, Takigawa S, Noda T. Traits of shattering resistant buckwheat 'W/SK86GF'. Breeding Sci. 2012;62(4):360-4. doi: 10.1270/jsbbs.62. 360.

20. Laemmli UK. Cleavage of structural proteins during the assembly of the head of bacteriophage T4. Nature. 1970;227:680-85. doi: 10.1038/227680a0. 